\title{
PENGGUNAAN MODEL PEMBELAJARAN PROBLEM POSING TERHADAP KEMAMPUAN BERPIKIR KRITIS SISWA
}

\author{
Cheri Saputra, Andre Mustofa Meihan \\ Email: cherysaputra@ fkip.unila.ac.id \\ FKIP Unila Jalan Prof. Dr. Soemantri Brojonegoro No. 01 Bandar Lampung
}

\begin{abstract}
Abstrak
Tujuan penelitian ini adalah untuk mengetahui "Apakah ada pengaruh antara penggunaan model pembelajaran Problem Posing terhadap kemampuan berpikir kritis siswa pada Mata Pelajaran Sejarah Indonesia Kelas X IPS SMA YP Unila Bandar Lampung Tahun Pelajaran 2018/2019”. Penelitian ini menggunakan metode penelitian Pre-Eksperimental Design dengan desain penelitian menggunakan One-Shot Case Studi. Teknik analisis data menggunakan rumus koefisien korelasi Jaspen's (M).Hasil penelitian menunjukan nilai Koefisien Korelasi Jaspen's (M) adalah 0,51. Berdasarkan tabel interpretasi korelasi, nilai koefisien korelasi Jaspen's sebesar 0,51termasuk dalam kategori kekuatan pengaruh cukup berarti atau sedang. Dengan demikian dapat disimpulkan, adapengaruh antara penggunaan model pembelajaran Problem Posing terhadapkemampuan berpikir kritis siswa pada Mata Pelajaran Sejarah Indonesia Kelas X IPS SMA YP Unila Bandar Lampung Tahun Pelajaran 2018/2019.
\end{abstract}

Kata kunci: Problem Posing, Pengaruh,Berpikir Kritis.

\section{Pendahuluan}

Proses belajar mengajar atau pembelajaran merupakan interaksi yang terjadi antara siswa sebagai peserta didik dengan guru sebagai pendidik pada suatu lingkungan belajar. Kewajiban seorang guru adalah memberikan bantuan terhadap murid untuk menyelesaikan masalah yang dialaminya, dan menyesuaikan diri dengan lingkungan belajar serta membantu siswanya agar dapat menerima pelajaran yang mereka sampaikan dengan baik yakni dengan memilih model yang baik dalam pembelajaran. Model pembelajaran adalah suatu konsep yang membantu menjelaskan proses pembelajaran, baik menjelaskan pola pikir maupun pola tindakan pembelajaran tersebut (Abidin, 2014: 117).

Melalui proses pembelajaran diharapkan seorang guru sebagai pengajar dapat menjadi penunjang dan pembimbing dalam mengembangkan kemampuan berfikir, terutama kemampuan berfikir kritis siswa, dengan berfikir kritis siswa tidak akan menerima materi begitu saja dan akan memberikan pertanyaan terhadap materi yang diberikan. Berpikir kritis adalah mengaplikasikan rasional, kegiatan berpikir yang tinggi, meliputi kegiatan menganalisis, 
mensintesis, mengenali permasalahan dan pemecahannya, menyimpulkan serta mengevaluasi (Angelo, 1993: 6-7).

Observasi yang dilakukan oleh peneliti di Kelas X IPS SMA YP Unila Bandar Lampung didapatkan data bahwa, proses belajar mengajar belum efektif dan optimal. Guru masih menjadi pusat dalam kegiatan pembelajaran atau istilahnya teacher centered, sehingga masih banyak siswa yang bersifat pasif pada saat proses belajar megajar berlangsung, padahal pada Kurikulum 2013 siswalah yang harusnya berperan lebih aktif dalam kegiatan pembelajaran. Kurikulum 2013 pada hakekatnya pembelajaran yang diarahkan untuk peserta didik mencari tahu bukan pembelajaran yang memberi tahu (Abidin, 2014: 17).

Keadaan ini membuat siswa menjadi tidak percaya diri dalam mengungkapkan pendapatnya. Berbagai upaya tentunya telah dicoba oleh guru, contohnya dengan menggunakan berbagai metode dalam pembelajaran, namun hasilnya masih saja belum optimal. Misalnya pada saat diskusi kelompok siswa masih banyak yang pasif dan tidak berani menyatakan pendapat. Proses pembelajaran yang tidak efektif dan optimal tentunya akan menghambat peningkatan kemampuan berpikir kritis siswa.

Kemampuan berpikir kritis termasuk kedalam ranah kognitif. Segala upaya yang menyangkut kegiatan mental (otak) adalah termasuk dalam ranah kognitif (Sudijono, 2008: 49). Dengan demikian kurang berkembangnya kemampuan berfikir kritis siswa dapat dilihat dari nilai hasil belajar kognitif siswa yang masih rendah.

Berdasarkan hasil penilaian proses belajar mengajar diperoleh data bahwa, kemampuan berpikir kritis siswa masih tergolong rendah, hal ini dapat dilihat dari banyaknya siswa yang belum mencapai KKM, selain itu siswa juga belum optimal melakukan serangkaian kegiatan berpikir kritis yang mengarah pada indikator kemampuan berpikir kritis (Wawancara dengan Ibu Siti Nursiah, M.Pd tanggal 06Oktober 2018). Indikator berpikir Kritis terdiri atas (1) Keterampilan Menganalisis, (2) Keterampilan mensitesis, (3) keterampilan mengenal dan memecahkan masalah, (4) keterampilan Menyimpulkan, (5) keterampilan Mengevaluasi atau menilai(Angelo, $1993: 13$ ).

Kurangnya kemampuan berpikir kritis ini tentunya akan membuat siswa tidak memunculkan ide-ide baru dan menemukan pengetahuan yang baru dalam kegiatan belajar 460 | Seminar Nasional Sejarah ke 4 Jurusan Pendidikan Sejarah Universitas Negeri Padang 
mengajar. Dengan adanya kemampuan berpikir kritis yang dimiliki siswa diharapkan dapat memecahkan masalah yang sedang mereka alami.Melihat kondisi tersebut diperlukan suatu upaya untuk menyelasaikan masalah ini. Salah satu langkah untuk menyelasaikan masalah tersebut adalah dengan menggunakan model pembelajaran yang sesuai dengan keadaan siswa, yaitu model pembelajaran Problem Posing.

Problem Posing merupakan model pembelajaran yang mengharuskan siswa menyusun pertanyaan sendiri atau memecah suatu soal dengan pertanyaan-pertanyaan yang lebih sederhana (Shoimin, 2014: 133). Menurut Thobroni dan Mustofa (2015: 288) model pembelajaran Problem Posing adalah suatu model pembelajaran yang mewajibkan para siswa untuk mengajukan soal sendiri melalui belajar soal (berlatih soal) secara mandiri.Pengajuan suatu soal tersebut merupakan tugas yang mengarah pada sikap kritis dan kreatif siswa, sebab siswa diminta untuk membuat pertanyaan dari informasi yang diberikan. Apabila dikaitkan dengan peningkatan kemampuan siswa, pengajuan soal merupakan sarana untuk merangsang kemampuan tersebut (Shoimin, 2014: 134).

Melihat beberapa pengertian ahli tersebut, pada saat pembelajaran menggunakan model Problem Posing terdapat beberapa aspek yang dapat diamati dari siswa yakni kemandirian, pemecahan masalah, dan kreatifitas siswa. Dengan ModelProblem Posing ini diharapkan siswa dapat meningkatkan kemampuan berpikir kritisnya.Salah satu kelebihan dari model Problem Posing adalah mendidik murid berpikir kritis (Shoimin, 2014: 135).

Berdasarkan latar belakang di atas, penulis tertarik untuk meneliti "Penggunaan Model Pembelajaran Problem Posing terhadap Kemampuan Berpikir Kritis Siswa Pada Mata Pelajaran Sejarah Indonesia Kelas X IPS SMA YP Unila Bandar Lampung Tahun Pelajaran 2018/2019". "Tujuan penelitian ini adalah untuk mengetahui apakah ada pengaruh antara penggunaan model pembelajaran Problem Posingterhadap kemampuan berpikir kritis siswa pada Mata Pelajaran Sejarah Indonesia Kelas X IPS SMA YP Unila Bandar Lampung Tahun Pelajaran 2018/2019”.

\section{Metode}

Metode penelitian diartikan sebagai cara ilmiah untuk mendapatkan data dengan tujuan dan kegunaan tertentu (Sugiyono, 2017: 3). Kemudian lebih lanjut lagi Sukardi menjelaskan, "Metodologi penelitian adalah usaha seseorang yang dilakukan secara sistematis mengikuti 461 | Seminar Nasional Sejarah ke 4 Jurusan Pendidikan Sejarah Universitas Negeri Padang 
aturan-aturan guna menjawab permasalahan yang hendak diteliti” (Sukardi, 2008: 19). Berdasarkan uraian tersebut menjelaskan bahwa metode penelitian merupakan langkah-langkah yang dilakukan oleh peneliti secara sistematis untuk memecahkan masalah dan mendapatkan jawaban yang tepat.

Pada penelitian ini metode yang digunakan adalah metode penelitian Pre-Eksperimental Design.Metode penelitian Pre-Eksperimental Design.memiliki bermacam-macam jenis desain. Jenis Desain dalam penelitian ini menggunakan One-Shot Case Studi.

Populasi adalah wilayah generalisasi yang terdiri atas: obyek/subyek yang mempunyai kualitas dan karakteristik tertentu yang ditetapkan oleh peneliti untuk dipelajari dan kemudian ditarik kesimpulannya (Sugiyono, 2017: 117). Populasi adalah seluruh data yang menjadi perhatian kita dalam suatu ruang lingkup dan waktu yang ditentukan, jadi populasi berpengaruh dengan data, bukan manusianya (Margono, 2007: 118). Total populasi dalam penelitian ini adalah seluruh siswa Kelas X IPS SMA YP Unila Bandar Lampung Tahun Pelajaran 2018/2019 sebanyak 93siswa.

Sampel adalah bagian dari jumlah dan karakteristik yang dimiliki oleh populasi tersebut (Sugiyono, 2017: 118). Sampling merupakan cara yang digunakan untuk mengambil sampel. Sampling bertujuan untuk menentukan sampel dalam suatu penelitian. Jumlah populasi dalam penelitian ini kurang dari 100, maka sampel dalam penelitian ini merupakan penelitian populasi. Hal tersebut didasarkan pada pendapat Arikunto bahwa "Untuk sekedar ancer-ancer maka apabila subjeknya kurang dari 100, lebih baik diambil semua sehingga penelitianya merupakan penelitian populasi” (Arikunto, 2006: 112).Berdasarkan teori di atas, karena jumlah populasi kurang dari 100 maka sampel dalam penelitian ini adalah seluruh siswa Kelas X IPS SMA YP Unila Bandar Lampung Tahun Pelajaran 2018/2019 sebanyak 93siswa.

Beberapa teknik dalam pengumpulan data yang digunakan oleh peneliti dalam penelitian ini adalah sebagai berikut :Observasi: Sutrisno Hadi (1986) dalam (Sugiyono, 2017: 203) mengemukakan bahwa observasi merupakan suatu proses yang kompleks, suatu proses yang tersusun dari berbagai proses biologis dan psikhologis. Teknik observasi yang dilakukan peneliti yakni observasi langsung. Observasi langsung adalah pengamatan dan pencatatan yang dilakukan terhadap objek di tempat terjadi atau berlangsungnya peristiwa (Margono, 2007:159). Observasi ini dilakukan peneliti selama melakukan penelitian di SMA YP Unila Bandar Lampung, dengan mengamati proses pembelajaran yang terjadi di dalam kelas. Tes. Tes atau 462 | Seminar Nasional Sejarah ke 4 Jurusan Pendidikan Sejarah Universitas Negeri Padang 
kuis merupakan alat atau prosedur yang digunakan untuk mengetahui atau mengukur sesuatu, dengan cara dan aturan-aturan yang sudah ditentukan (Arikunto, 2006: 52). Tes adalah suatu alat pengukur yang berupa serangkaian pertanyaan yang harus dijawab secara sengaja dalam suatu situasi yang distandarisasikan, dan yang dimaksudkan untuk mengukur kemampuan dan hasil belajar individu atau kelompok (Masidjo,1995: 38). Dalam hal ini kemampuan yang akan diukur dengan menggunakan tes ialah kemampuan berpikir kritis.Kemampuan berpikir kritis termasuk ke dalam ranah kognitif yang mana terdapat aspek pemahaman, penerapan, dan penalaran. Berpikir Kritis dan kreatif digunakan dalam upaya memecahkan masalah (problem solving). Pemecahan masalah yaitu menggunakan (yaitu mentransfer) pengetahuan dan keterampilan yang sudah ada untuk menjawab pertanyaan yang belum terjawab atau situasi yang sulit (Ormrod, 2009: 393).Berdasarkan keterkaitan konsep tes dan konsep kemampuan berfikir kritis, maka dalam penelitian ini menggunakan teknik pengumpulan data dengan tes yang berbentuk Esay atau uraian. Tes Esay adalah suatu bentuk tes tertulis yang susunanya tediri atas item-item pertanyaan yang masing-masing mengandung permasalahan dan menuntut jawaban siswa melalui uraian- uraian kata yang merefleksikan kemampuan berpikir siswa (Sukardi,2008:94).

Dokumentasi. Dokumentasi adalah cara mengumpulkan data melalui peninggalan-peninggalan tertulis, terutama berupa arsip-arsip dan termasuk juga buku-buku tentang pendapat, teori, dalil atau hukum-hukum lain yang berpengaruh dengan masalah penyelidikan (Nawawi, 1991:133). Dokumentasi dilakukan dengan cara pengambilan data yang telah ada, seperti data siswa Kelas X IPS SMA YP Unila Bandar Lampung, serta penilaian harian terakhir Kelas X SMA YP Unila Bandar Lampung Tahun Pelajaran 2018/2019. Wawancara. "Wawancara merupakan salah satu teknik pengumpulan data yang dilakukan dengan cara mengadakan tanya jawab, baik secara langsung maupun tidak langsung dengan sumber data" (Mohammad Ali, 1992: 64). Wawancara yang digunakan yaitu wawancara tidak terstruktur dengan Guru Sejarah Indonesia SMA YP Unila Bandar Lampung. Kepustakaan. Kepustakaan dapat diartikan sebagai studi penelitian yang dilaksanakan dengan cara mendapatkan sumber-sumber data yang diperoleh di perpustakaan yang melalui buku-buku literatur yang berkaitan dengan masalah yang diteliti (Nawawi, 1991:133). Teknik ini digunakan untuk memperoleh data-data yang berpengaruh dengan penulisan dalam penelitian ini, seperti : konsep-konsep dalam penelitian, teori yang mendukung, serta data-data pendukung yang diambil dari berbagai referensi. 
Sebelum melaksanakan penelitian, peneliti terlebih dahulu menyiapkan instrumen yang nantinya akan digunakan dalam penelitian. Instrumen yang akan digunakan mengukur kemampuan siswa ini haruslah diuji terlebih dahulu untuk mengetahui layak atau tidaknya instrumen tersebut digunakan sebagai alat ukur penelitian. Uji yang dipakai adalah uji validitas, uji reliabilitas, uji tingkat kesukaran, danuji daya pembeda.

Uji validitas instrumen dalam penelitian ini menggunakan rumus korelasi product moment pearson dengan taraf signifikan 0,05 dan jumlah murid atau $n=34$ jadi $r_{\text {tabel }}$ sebesar 0,339. Kriteria uji jika $r_{\text {hitung }}>r_{\text {tabel }}$ maka butir soal tersebut dinyatakan valid. Perhitungan uji validitas instrumen peneliti lakukan dengan cara manual, selain itu jugapeneliti menggunakan bantuan program Microsoft Excel 2007. Setelah uji validitas kemudian dilakukan uji reliabilitas instrumen.

Uji reliabilitas dilakukan untuk untuk mengetahui apakah butir soal instrumen yang digunakan tersebut reliabel (konsisten) atau tidak. Uji reliabilitas dilakukan menggunakan rumus Alpha Cronbach. Setelah soal dinyatakan valid dan reliabel, selanjutnya setiap butir soal dihitung tingkat kesukarannya. Sebab soal yang baik adalah soal yang tidak terlalu mudah atau terlalu sukar untuk dikerjakan oleh siswa. Setelah itu kemudian dicari daya beda soal.

Sesudah dilakukan uji prasayarat analisis data yang meliputi normalitas dan homogenitas. Data telah memenuhi syarat analisis data, maka tahap selanjutnya adalah melakukan uji hipotesis.Hipotesis berasal dari Bahasa Yunani Hipo (Sementara) dan Thesa pernyataan atau teori. Hipotesis adalah suatu jawaban yang bersifat sementara terhadap permasalahan peneliti, sampai terbukti melalui data yang terkumpul (Arikunto, 2006: 71),sedangkan pendapat lain mengatakan hipotesis merupakan jawaban sementara terhadap rumusan masalah penelitian, dimana rumusan masalah penelitian telah dinyatakan dalam bentuk kalimat pertanyaan (Sugiyono, 2017: 96).

Uji hipotesis merupakan langkah untuk memberikan jawaban terhadap rumusan masalah dalam penelitian.Adapun hipotesis yang akan di uji kebenarannya adalah sebagai berikut:

$\mathrm{H}_{0}=$ Tidak ada pengaruhantara penggunaan model pembelajaran Problem Posingterhadap kemampuan berpikir kritis siswa pada Mata Pelajaran Sejarah IndonesiaKelas X SMA YP Unila Bandar Lampung Tahun Pelajaran 2018/2019. 
$\mathrm{H}_{1}=$ Ada pengaruh antara penggunaanmodel pembelajaran Problem Posingterhadap kemampuan berpikir kritis siswa pada Mata Pelajaran Sejarah Indonesia Kelas X IPS SMA YP Unila Bandar Lampung Tahun Pelajaran 2018/2019.

Setelah data penelitian diperoleh, lalu dianalisis yang bertujuan mengetahui apakah adapengaruh antara penggunaan model pembelajaran problem posing terhadap kemampuan berpikir kritis siswa. Analisis data yang peneliti gunakan yaitu :

rumus koefisien korelasi Jaspen's (M) sebagai berikut :

$\mathbf{M}=\frac{\Sigma\left(\sigma_{1}\right)\left(O_{b}-O_{a}\right)}{\left(s_{y}\right) \Sigma\left(\frac{\left(O_{b}-O_{b}\right)^{2}}{p}\right)}$

(Misbahudin dan Iqbal Hasan, 2013:64)

Setelah didapat nilai koefiien korelasi Jaspen's (M) maka dapat diketahui arti dari nilai koefisien korelasi dengan melihat tabel interval nilai koefisien korelasi sebagai berikut

Tabel 1. Interval Nilai Koefisien Korelasi dan Kekuatan Pengaruh

\begin{tabular}{|c|l|l|}
\hline $\begin{array}{c}\text { No } \\
\cdot\end{array}$ & \multicolumn{1}{|c|}{ Interval Nilai } & \multicolumn{1}{c|}{ KekuatanPengaruh } \\
\hline 1 & $\mathrm{KK}=0,0$ & Tidak ada \\
\hline 2 & $0,00<\mathrm{KK} \leq 0,20$ & Sangat rendah atau lemah sekali \\
\hline 3 & $0,20<\mathrm{KK} \leq 0,40$ & Rendah atau lemah, tapi pasti \\
\hline 4 & $0,40<\mathrm{KK} \leq 0,70$ & Cukup berarti atau sedang \\
\hline 5 & $0,70<\mathrm{KK} \leq 0,90$ & Tinggi atau kuat \\
\hline 6 & $0,90<\mathrm{KK} \leq 1,00$ & Sangat tinggi atau kuat sekali, dapat diandalkan \\
\hline 7 & $\mathrm{KK}=1,00$ & Sempurna \\
\hline
\end{tabular}

Sumber :(Misbahudin dan Iqbal Hasan, 2013: 48)

\section{Hasil dan Pembahasan}

Rumusan masalah dalam penelitan ini adalah "Apakah ada pengaruh antara penggunaan model pembelajaran Problem Posing terhadap kemampuan berpikir kritis siswa pada Mata Pelajaran Sejarah Indonesia Kelas X IPS SMA YP Unila Bandar Lampung Tahun Pelajaran 2018/2019 ?’.Penelitian ini dilaksanakan untuk mengetahui ada atau tidaknya pengaruhantara penggunaan model pembelajaran problem posingterhadap kemampuan berpikir kritis siswa pada 
Mata Pelajaran Sejarah Indonesia Kelas X IPS SMA YP Unila Bandar Lampung Tahun Pelajaran 2018/2019.

Penelitian ini menggunakan metode penelitian Pre-experimentaldesign, adapun jenis desain penelitiannya yakni one shoot case study. Populasi dari penelitian ini adalah siswa Kelas X IPS SMA YP Unila Bandar Lampung, karena jumlah populasi dalam penelitian ini kurang dari 100, sehingga untuk sampel dalam penelitian ini adalah seluruh siswa KelasX IPS SMA YP Unila Bandar Lampung.

Pemilihan lokasi penelitian di SMA YP Unila Bandar Lampung dilakukan karena beberapa pertimbangan. pertama peneliti memiliki kedekatan dengan beberapa guru yang ada di SMA YP Unila Bandar Lampung sehingga memudahkan peneliti untuk memeperoleh data yang diperlukan. Kedua, jarak yang ditempuh tidak terlalu jauh dari institusi peneliti, sehingga hal tersebut membuat peneliti dapat meminimalisir biaya penelitian. Pertimbangan ketiga adalah secara umum memiliki keterkaitan dengan permasalahan yang menjadi latar belakang penelitian, alasan pemilihan SMA YP Unila sebagai tempat penelitian karena, SMA YP Unilasudah menerapkan Kurikulum 2013 yang memiliki banyak aspek penlaian berpikir kritis siswa.

Kemampuan berpikir kritis siswa Kelas X IPS SMA YP Unilaterbilang masih kurang berkembang. Hal tersebutlah yang mendasari peneliti melakukan penelitian di SMA YP Unila sebagai tempat penelitian. Dimana peneliti melakukan eksperimen untuk dapat mengembangkan kemampuan berpikir kritis siswa dengan cara menerapkan sebuah model pembelajaranProblem Posing dengan membuat siswa lebih mandiri dalam belajar sehingga dapat mencapai tujuan pembelajaran.

Sebelum melaksanakan penelitian, peneliti terlebih dahulu menyiapkan instrumen yang nantinya akan digunakan dalam penelitian. Instrumen yang akan digunakan mengukur kemampuan siswa ini haruslah diuji terlebih dahulu untuk mengetahui layak atau tidaknya instrumen tersebut digunakan sebagai alat ukur penelitian. Uji yang dipakai adalah uji validitas, uji reliabilitas, uji tingkat kesukaran dan, uji daya pembeda.

Uji validitas instrumen dalam penelitian ini menggunakan rumus korelasi product moment pearson dengan taraf signifikan 0,05 dan jumlah murid atau $n=34$ jadi $r_{\text {tabel }}$ sebesar 0,339. Kriteria uji jika $r_{\text {hitung }}>r_{\text {tabel }}$ maka butir soal tersebut dinyatakan valid. Perhitungan uji 
validitas instrumen peneliti lakukan dengan cara manual. Berdasarkan hasil pengujian butir soal yang terdiri dari 5 soal essay tiap posttest, dapat diketahui bahwa semua butir soal valid.Setelah uji validitas kemudian dilakukan uji reliabilitas instrumen.

Uji reliabilitas dilakukan untuk mengetahui apakah butir soal instrumen yang digunakan tersebut reliabel (konsisten) atau tidak. Uji reliabilitas dilakukan menggunakan rumus Alpha Cronbach. Dari uji reliabilitas instrumen posttest 1 menunjukan nilai reliabilitas adalah 0,53 yang berdasarkan kriteria reabilitas berarti cukup. Instrumen posttest 2 menunjukan angka 0,55 yang berarti cukup, dan isntrumen posttest 3 reabilitasnya 0,64 yang berarti tinggi.

Soal yang dinyatakan valid dan reliabel, selanjutnya setiap soal dihitung tingkat kesukarannya. Soal posttest 1 yang terdiri dari 5 butir soal essay memiliki kategori mudah 4 butir soal dan cukup 1 butir soal. Soal posttest 2 yang terdiri dari 5 butir soal essay memiliki kategori mudah 4 butir soal dan cukup 1 butir soal. Soal posttest 3 yang terdiri dari 5 butir soal essay memiliki kategori mudah untuk semua soal.

Selanjutnya dicari daya beda soal. Daya pembeda atau daya beda bertujuan untuk membedakan antara siswa yang pandai atau berkemampuan tingi dengan siswa yang bodoh atau berkemampuan rendah. Berdasarkan uji daya pembeda terdapat soal-soal yang memiliki kategori sedang dan baik. Setelah uji instrumen telah dilakukan, kemudian penelitian siap dilaksanakan.

Model pembelajaran Problem Posing merupakan suatu model pembelajaranyang baru diterapkan di SMA YP Unila khususnya pada Kelas X IPS yang menjadi sampel penelitian. Pembelajaran menggunakan model problem posingini dilaksanakan dalam 3 kali pertemuan dengan alokasi waktu 2 jam tiap pertemuan, pertemuan dilakukan di Kelas X IPS 1, 2, dan 3.

Penelitian dimulai sejak tanggal 24 Oktober s/d 7November 2018 dengan materi asal usul nenek moyang bangsa Indonesia. Hasil penelitian berupa data kuantitatif yang terdiri dari data kemandirian siswa dan kemampuan berpikir kritis siswa yang diamati dan diukur selama 3 kali pertemuan melalui lembar observasi dan tes.

Langkah pembelajaran dalam setiap pertemuan yaitu peneliti mengkondisikan kelas dengan memeriksa kelengkapan siswa dan kehadiran siswa, peneliti menyampaikan "kontrak belajar " dan tujuan belajar. peneliti menyampaikan target belajar hari ini,peneliti memberikan 
stimulasi dengan menceritakan ilustrasi yang mengarahkan siswa mengambil kesimpulan tentang asal usul nenek moyang bangsa Indonesia.

Kemudian kegiatan inti, peneliti membagi siswa kedalam kelompok. Masing-masing siswa dalam kelompok membentuk pertanyaan berdasarkan hasil pengamatan yang telah dibuat dalam lembar Problem PosingI.Pertanyaan dikumpulkan kemudian dilimpahkan pada kelompok yang lainnya. Misalkan tugas membentuk pertanyaan kelompok 1 diserahkan kepada kelompok 2 untuk dijawab dan dikritisi. Tugas kelompok 2 diserahkan kepada kelompok 3, dan seterusnya hingga kelompok terakhir kepada kelompok 1.Setiap siswa dalam kelompoknya melakukan diskusi untuk menjawab pertanyaan yang siswa terima dari kelompok lain.Setiap jawaban ditulis pada lembar Problem Posing II atau lembar jawaban. Setiap kelompok mempresentasikan hasil dikusinya dan pertanyaan yang telah dibuat kelompok lain.

Selanjutnya adalah tahap akhir peneliti dan siswa mengambil kesimpulan dari hasil pembelajaran hari ini dan peneliti memberikan soal posttest kepada siswa, kemudian peneliti menutup pertemuan.Data yang diperoleh pada pertemuan ini adalah berasal dari lembar observasi pada saat model pembelajaran Problem Posingberlangsung, serta pemberian posttest diakhirpembelajaran untuk mengukur kemampuan berpikir kritis siswa.

Untuk mengukur kemampuan berpikir kritis dilakukan dengan memberikan posttest yang berkaiatan dengan indikator kemampuan berpikir kritis yaitu menganalisis, pemecahan masalah, dan evaluasi. Jumlah soal posttest berpikir kritis ini berjumlah 5 soal dengan rentang skor 5-20, sehingga apabila siswa menjawab semua soal dengan benar skor maksimal adalah 100.

Skor berpikir kritis tersebut dikonversikan menjadi nilai yang siap diolah, kemudian nilai beripikir kritis tersebut direkapitulasi dan dirata-ratakan. Setelah itu nilai yang didapat kemudian dikategorisasikandan didapatkan kategori siswa yang memiliki nilai tinggi berada pada rentang nilai di atas 82 yang berjumlah 30 siswa, siswa yang memiliki kemandirian sedang berada pada rentang 68-82 yang berjumlah 63siswa.Pada kategori berpikir kritis, siswa yang memiliki kemampuan berpikir kritis tinggi berada pada rentang nilai di atas 86 berjumlah 23 siswa, siswa yang memiliki kemampuan berpikir kritis sedang berada pada rentang 76-86 dengan jumlah 50 siswa, dan siswa yang memiliki kemampuan berpikir kritis rendah berada pada rentang nilai di bawah 76 berjumlah 20 siswa. 
Sebelum melakukan analisis data perlu dilakukan uji normalitas dan homogenitas terlebih dahulu.

Uji normalitas dilakukan untuk mengetahui data yang diperoleh berdistribusi normal atau tidak. Uji yang dilakukan dengan menggunakan Uji Chi Kuadrat dengan dk = 7 dan taraf nyatanya 0,05. Jika $X_{\text {hitung }}<X_{\text {tabel }}$ maka data berdistribusi normal, sedangkan jika $X_{\text {hitung }}>X_{\text {tabel }}$ maka data berdistribusi tidak normal. Adapun data yang diuji adalah data rata-rata berpikir kritis siswa. Hasil pengujian normalitas data dapat dilihat pada tabel berikut :

\section{Tabel 2. Hasil Uji Normalitas}

\begin{tabular}{|c|c|c|c|c|}
\hline Data & $\mathbf{X}_{\text {hitung }}$ & Dk & $\mathbf{X}_{\text {tabel }}$ & Keterangan \\
\hline Kemandirian & 9,01 & 7 & 14,07 & Normal \\
\hline Berpikir kritis & 11,36 & 7 & 14,07 & Normal \\
\hline
\end{tabular}

Sumber: Hasil olah data peneliti tahun 2018

Terlihat dari tabel tersebut bahwa uji nomalitas berpikir kritis untuk taraf nyata 0,05 dengan $\mathrm{dk}=7$, diperoleh $\mathrm{X}_{\text {hitung }}=9,01$ dan $\mathrm{X}_{\text {tabel }}=14,07$. Karena $\mathrm{X}_{\text {hitung }}<\mathrm{X}_{\text {tabel, }}$ maka dapat disimpulkan bahwa data tersebut berdistribusi normal. $\quad$ Uji homogenitas dilakukan untuk mengetahui apakah data dari berpikir kritis siswa memiliki varian yang sama (homogen) atau tidak. Uji kesamaan dua varian data dilakukan dengan pembagian antara varian terbesar dengan varian terkecil. Kriteria pengujian yang digunakan untuk taraf 0,05 dan dk =(v1,v2). Jika $F_{\text {hitung }}<F_{\text {tabel }}$ maka data tersebut homogen, dan sebaliknya jika $F_{\text {hitung }}>F_{\text {tabel, }}$, maka data tersebut tidak homogen (heterogen). Hasil perhitungan uji homogenitas dapat dilihat pada tabel berikut :

Tabel 3. Hasil Uji Homogenitas

\begin{tabular}{|c|c|c|c|c|}
\hline Data & Varian & F $_{\text {hitung }}$ & $\mathbf{F}_{\text {tabel }}$ & Keterangan \\
\hline Kemandirian & 7,10 & \multirow{2}{*}{1,33} & \multirow{2}{*}{1,40} & Homogen \\
\hline Berpikir kritis & 5,35 & \multirow{2}{*}{1,33} & \\
\hline
\end{tabular}

Sumber: Hasil olah data peneliti tahun 2018

Pada taraf 0,05 dan $\mathrm{dk}=(\mathrm{V} 1, \mathrm{~V} 2)=(93,93)$ didapat $\mathrm{F}_{\text {tabel }}$ sebesar 1,40. Perhitungan yang dilakukan menunjukan besarnya $F_{\text {hitung }}=1,33<\mathrm{F}_{\text {tabel }}=1,40$ pada taraf nyata $5 \%$, sehingga dapat disimpulkan bahwa data penelitian mempunyai varian yang sama atau homogen. 
Kemudian tahap selanjutnya adalah melakukan pengujian hipotesis guna menguji apakah ada pengaruh antara penggunaan model pembelajaran Problem Posing terhadap kemampuan berpikir kritis siswa, maka digunakan rumus koefisien korelasi Jaspen's (M).

Berdasarkan uji analisis data yang dilakukan dengan menggunakan rumus KorelasiJaspen's, didapat data yaitu nilai koefisien korelasi Jaspen ' $s=0,51$,yang menyatakan ada pengaruh antara penggunaan model pembelajaran Problem Posingterhadap kemampuan berpikir kritis siswa pada Mata Pelajaran Sejarah Indonesia. Dan berdasarkan tabel interpretasi korelasi, nilai koefisien korelasi Jaspen's sebesar 0,51termasuk dalam kategori kekuatan pengaruh cukup berarti atau sedang.

Berdasarkan penjabaran dan hasil analisis data menunjukan bahwa hipotesis nol $\left(\mathrm{H}_{0}\right)$ ditolak dan hipotesis alternatif $\left(\mathrm{H}_{1}\right)$ diterima, hal tersebut membuktikan bahwa ada pengaruh antara penggunaan model pembelajaran Problem Posingterhadap kemampuan berpikir kritis siswa pada Mata Pelajaran Sejarah Indonesia Kelas X IPS SMA YP Unila Bandar Lampung Tahun Pelajaran 2018/2019.

\section{Simpulan}

Berdasarkan penjabaran dan analisis data yang dilakukan dari perhitungan mengenai pengaruh antara penggunaan model pembelajaran Problem Posing terhadap kemampuan berpikir kritis siswa pada Mata Pelajaran Sejarah Indonesia Kelas X IPS SMA YP Unila Bandar Lampung Tahun Pelajaran 2018/2019, dapat disimpulkan bahwa :

Ada pengaruh antara penggunaan model pembelajaran Problem Posing terhadap kemampuan berpikir kritis siswa pada Mata Pelajaran Sejarah Indonesia Kelas X IPS SMA YP Unila Bandar Lampung Tahun Pelajaran 2018/2019, hal ini dapat dilihat dari perhitungan koefisien korealasi Jaspen'ssebesar 0,51termasuk dalam kategori kekuatan pengaruh cukup berarti atau sedang.

\section{DAFTAR PUSTAKA}

Angelo, T. A., Cross, K.P. 1993. Classroom Assessment Techniques: A Handbook For College Teachers. San francisco: Jossey-Bass.

470 | Seminar Nasional Sejarah ke 4 Jurusan Pendidikan Sejarah Universitas Negeri Padang 
Arikunto, Suharsimi. 2006. Prosedur Penelitian Suatu Pendekatan Praktik. Jakarta: Rineka Cipta.

Madsidjo, 1995. Penilaian Pencapaian Hasil Belajar Siswa di Sekolah. Yogyakrta: Kanisius.

Misbahuddin dan Iqbal Hasan. 2013. Analisis Data Penelitian denganStatistik.Jakarta: BumiAksara.

Nawawi,Hadari.1991.MetodePenelitianBidangSosial.Yogyakarta:GadjahMadaUniversityPress.

Ormrod, J. E. 2009. Eduction Psychology, Developing learners. Ohio: Carlisle Communication, Ltd.

S. Margono. 2007. Metodologi Penelitian Pendidikan. Jakarta: Rineka Cipta.

Shoimin, Aris. 2014. 68 Model Pembelajaran Inovatif dalam Kurikulum 2013. Yogyakarta : ArRuzz Media.

Sudijono,Anas.2008.PengantarEvaluasiPendidikan.Jakarta:RajaGrafindoPersada.

Sugiyono. 2017. Metode Penelitian Pendidikan (Pendekatan Kuantitatif, Kualitatif,danR\&D).Bandung: Alfabeta

Sukardi. 2008. Metodologi Penelitian Pendidikan. Jakarta: Bumi Aksara.

Thobroni, M dan Arif Mustofa. 2015. Belajar dan Pembelajaran. Yogyakarta: Ar-ruzz Media. 